Wright, J. R., J. A. Johnson, E. Bayne, L. L. Powell, C. R. Foss, J. C. Kennedy, and P. P. Marra. 2021. Migratory connectivity and annual cycle phenology of Rusty Blackbirds (Euphagus carolinus) revealed through archival GPS tags. Avian Conservation and Ecology 16(1):20. https://doi. org/10.5751/ACE-01871-160120

Copyright (C 2021 by the author(s). Published here under license by the Resilience Alliance.

Research Paper

\title{
Migratory connectivity and annual cycle phenology of Rusty Blackbirds (Euphagus carolinus) revealed through archival GPS tags
}

\author{
James R. Wright ${ }^{1}$, James A. Johnson ${ }^{2}$, Erin Bayne ${ }^{3}$, Luke L. Powell ${ }^{4,5}$, Carol R. Foss ${ }^{6}$, Jeremiah C. Kennedy ${ }^{3}$ and Peter P. Marra ${ }^{4,7}$ \\ ${ }^{1}$ School of Environment and Natural Resources, The Ohio State University, Columbus, OH, USA, ${ }^{2}$ U.S. Fish and Wildlife Service, \\ Migratory Bird Management, Anchorage, Alaska, USA, ${ }^{3}$ Department of Biological Sciences, University of Alberta, Edmonton, \\ AB, Canada, ${ }^{4}$ Migratory Bird Center, Smithsonian Conservation Biology Institute, National Zoological Park, Washington, DC, \\ USA, ${ }^{5}$ Current address: Institute of Animal Health and Comparative Medicine, University of Glasgow, Glasgow, UK, ${ }^{6}$ New \\ Hampshire Audubon, Concord, NH, USA, ${ }^{7}$ Current address: Department of Biology and McCourt School of Public Policy, \\ Georgetown University, Washington, DC, USA
}

\begin{abstract}
Understanding spatial and temporal movement patterns of migratory birds throughout the annual cycle can help identify potential population threats. The behavior and habitat use of birds during migration and stopover periods is particularly understudied in many species. In this study, we used high spatial resolution archival GPS tags to track Rusty Blackbirds (Euphagus carolinus) from one eastern (New Hampshire) and two western (Alaska and Alberta) breeding populations across the annual cycle. We sought to determine: 1) migratory connectivity of the three distinct populations; 2) migratory phenology, behavior, and time spent during each phase of the annual cycle; and 3) habitat use of individuals throughout the nonbreeding period. We retrieved 7 tags from 30 tagged individuals following 1-year deployments. We found that four Alberta individuals overwintered in the Mississippi Alluvial Valley, two Alaska individuals overwintered in either the Great Plains or the Mississippi Alluvial Valley, and the single New Hampshire individual overwintered on the Southeastern Coastal Plain. Length of annual cycle stages varied among individuals, with the combined migratory periods occupying between $12 \%$ and $48 \%$ of the annual cycle. Stopover behavior was also widely variable, as minimum convex polygons of stopovers ranged from $<1$ hectare to $505 \mathrm{~km}^{2}$ and stopover durations ranged from 1 to 35 days ( $\mathrm{n}=40$ stopovers). Birds predominantly used woody wetlands and emergent marsh during the nonbreeding period, but habitat use differed between roosting and foraging. Marshes were used more for nocturnal roosting, whereas woody wetlands were used for diurnal foraging. Our results can help efforts to conserve this declining species by targeting regions and habitats at specific times of year for management during the nonbreeding period. In particular, the large amount of time spent during migration periods suggests conservation efforts in stopover regions are just as important as those on the wintering grounds.
\end{abstract}

\section{Connectivité migratoire et phénologie du cycle annuel chez le quiscale rouilleux (Euphagus carolinus) révélées par les balises GPS archivées}

RÉSUMÉ. La compréhension des habitudes de déplacements spatiaux et temporels des oiseaux migrateurs tout au long du cycle annuel peut permettre d'identifier les menaces potentielles pour ces populations. L'utilisation du comportement et de l'habitat des oiseaux pendant les périodes de migration et d'escales est particulièrement sous-étudiée chez de nombreuses espèces. Dans cette étude, nous avons utilisé des balises GPS d'archivage à haute résolution spatiale pour suivre les quiscales rouilleux (Euphagus carolinus) d'une population de reproduction de l'est du pays (New Hampshire) et de deux populations de l'ouest (Alaska et Alberta) tout au long du cycle annuel. Nous cherchions à déterminer : 1) la connectivité migratoire des trois populations distinctes ; 2) la phénologie migratoire, le comportement et le temps consacré à chaque phase du cycle annuel; et 3) l'utilisation de l'habitat par les individus tout au long de la période hors reproduction. Nous avons récupéré 7 balises sur 30 individus bagués à la suite de déploiements d'un an. Nous avons constaté que quatre individus de l'Alberta avaient passé l'hiver dans la vallée alluviale du Mississippi, que deux individus de l'Alaska avaient séjourné dans les grandes plaines de la vallée alluviale du Mississippi et qu'un seul individu du New Hampshire avait passé l'hiver dans la plaine côtière du sud-est. La durée des différentes phases du cycle annuel variait selon les individus, les périodes migratoires combinées représentant entre $12 \%$ et $48 \%$ du cycle annuel. Le comportement en termes d'escales était également très variable, car les polygones convexes minimum des escales variaient de $<1$ hectare à $505 \mathrm{~km}^{2}$ et la durée des escales variait de 1 à 35 jours ( $\mathrm{n}=40$ escales). Les oiseaux choisissaient en majorité des régions marécageuses boisées et des marais émergents au cours de la période hors-reproduction, mais l'utilisation de l'habitat variait entre la nidification et la recherche de nourriture. Les marais étaient davantage utilisés pour la nidification nocturne, alors que les marécages boisés étaient privilégiés pour la recherche de nourriture diurne. Nos résultats peuvent favoriser les efforts de préservation de cette espèce en déclin, en ciblant les régions et les habitats au cours de périodes spécifiques de l'année pour la gestion hors de la période de reproduction. Plus précisément, les longues périodes de migration suggèrent que les efforts de conservation dans les régions d'escale sont tout aussi importants que ceux qui sont réalisés sur les territoires d'hivernage.

Key Words: bird migration; Euphagus carolinus; full annual cycle; habitat use; Icteridae; life-history stages; stopover ecology 


\section{INTRODUCTION}

Understanding the spatial and temporal distribution of migratory bird populations throughout the annual cycle is crucial for effective conservation. Specifically, prior to species-level management plans being developed and implemented, it is necessary to know where individuals and populations of a particular species go and how much time they spend in their various life-history stages (e.g., breeding, migration, wintering). For example, the migration period is particularly understudied (Marra et al. 2015), but it is especially critical to understand threats during this period because for many species mortality is highest during migration (Sillett and Holmes 2002, Klaassen et al. 2014, Rushing et al. 2017, Ward et al. 2018). In addition, it is important to recognize the different scales at which conservation action is needed. At a continental scale, understanding migratory connectivity, or the extent to which individuals at a breeding area use the same areas during the nonbreeding season (Webster et al. 2002), is essential to identify particular geographic regions that are important to the species or population of interest. If migratory connectivity between breeding and wintering grounds is weak, with multiple breeding populations wintering in one region, then that region may be crucial to supporting the species as a whole (e.g., Tonra et al. 2019a). If migratory connectivity is strong, with different breeding populations wintering in unique areas, then conservation action must be more targeted to the population of interest (e.g., Kramer et al. 2018). Finally, at a local patch scale, identifying the habitat types used by migratory birds during each stage of the annual cycle will help land managers protect critical habitat in the appropriate season (Reynolds et al. 2017).

Migratory birds in North America have declined precipitously over the last 50 years (Rosenberg et al. 2019). The Rusty Blackbird (Euphagus carolinus), a once common species, has undergone declines of between $85-95 \%$ since the 1960 s, with qualitative evidence of declines stretching back to at least the early $20^{\text {th }}$ century (Greenberg and Droege 1999, Niven et al. 2004). Rusty Blackbirds breed across the North American boreal zone from Alaska to Newfoundland, where they are patchily distributed throughout forested or shrubby wetlands and riparian zones (Avery 2020). During the winter, they are found primarily in bottomland hardwood forest-dominated regions of the eastern United States, in particular the lower Mississippi Alluvial Valley and the Southeastern Coastal Plain. Previous studies have attempted to find explanations for their rapid decline (e.g., Barnard et al. 2010, Edmonds et al. 2010, McClure et al. 2012) and fill knowledge gaps in their life history. For example, numerous local studies have helped refine our knowledge of their resource requirements on the breeding and wintering grounds through point counts, radio telemetry, and nesting surveys (e.g., Luscier et al. 2010, Matsuoka et al. 2010, Powell et al. 2014, Mettke-Hofmann et al. 2015). Less is known about migratory behavior and habitat use during migration (but see Wright et al. 2018a, Wright et al. 2020). Two studies have begun to describe the migratory connectivity of Rusty Blackbird populations. First, using stable hydrogen isotopes to assess latitudinal patterns of migratory connectivity, one study suggested the Appalachians serve as a migratory divide between eastern and western breeding populations, with birds south and east of Hudson Bay wintering in the Southeastern Coastal Plain, and birds west of Hudson Bay wintering in the Mississippi Alluvial Valley (Hobson et al. 2010).
Although this study was useful in demonstrating a migratory divide, the low precision of feather stable isotope data only allowed for the identification of two breeding populations, when more subdivisions are likely with such a widespread breeding range. A second study using light-level geolocators found that three birds breeding in Alaska (Fig. 1) used similar flyways for both fall and spring migration, but overwintered in different areas of the Great Plains and Mississippi Alluvial Valley (Johnson et al. 2012). These more precise, individual-level data helped to identify differences in migration within a population, but their applicability to the species as a whole is limited by the single breeding site and high spatial uncertainty of the geolocator data.

Fig. 1. Migratory connectivity and GPS tracks of tagged Rusty Blackbirds (Euphagus carolinus) from three breeding populations. Red, yellow, and blue areas indicate the approximate breeding, migration, and wintering ranges respectively. Black lines outline the three core wintering areas (A = Great Plains, $\mathrm{B}=$ Mississippi Alluvial Valley, $\mathrm{C}=$ Southeastern Coastal Plain). Solid orange, purple and green lines display the GPS tracks of tagged individuals from Alaska $(n=2)$, Alberta $(n=4)$, and New Hampshire $(n=1)$. Dotted lines show the connections between breeding and wintering areas of band recoveries $(\mathrm{n}=1$, in blue) and geolocator birds ( $\mathrm{n}$ $=3$, in black) from a previous study.

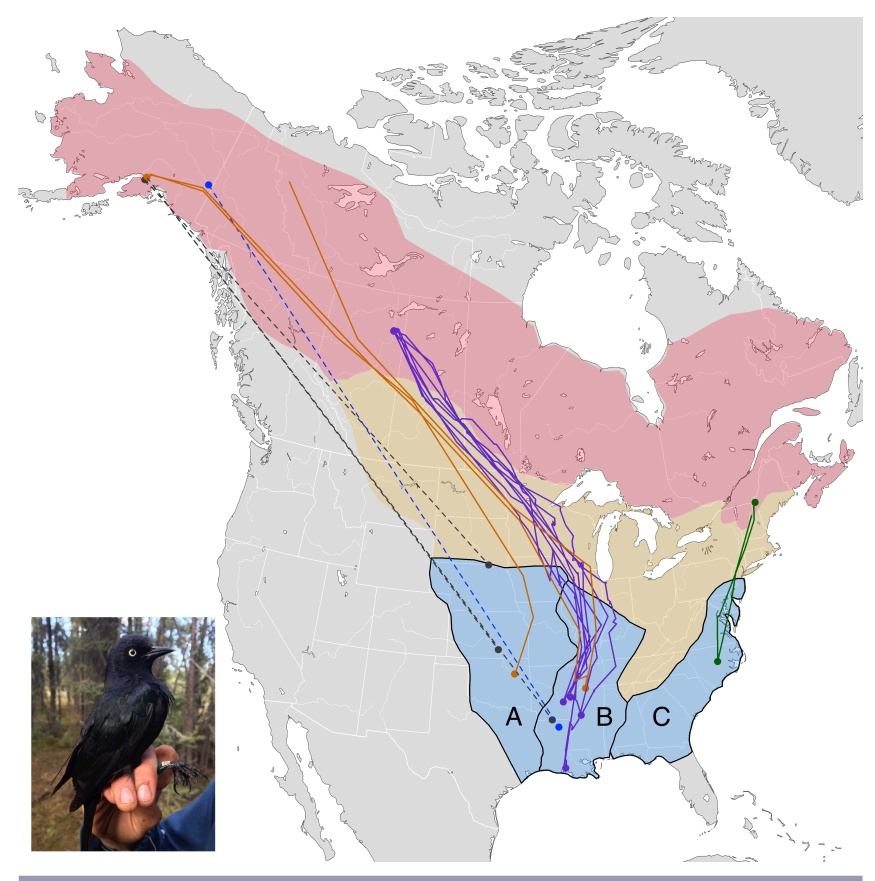

Here, we used pinpoint GPS technology to assess the migratory connectivity and full annual cycle ecology of three geographically distinct Rusty Blackbird breeding populations. Our objectives were to: 1) determine the migratory routes and wintering sites of the three populations; 2) quantify migratory behavior and the phenology of the annual cycle; and 3) given the high spatial resolution of the tags, use remotely sensed habitat data to determine patterns of habitat use throughout the nonbreeding period. 


\section{METHODS}

\section{Tag deployment and recovery}

We captured breeding Rusty Blackbirds during May-June 2015, 2017, and 2018 at three sites: Anchorage, Alaska, USA (61.282, -149.753), Fort McMurray, Alberta, Canada (57.473, -111.403), and Coos County, New Hampshire, USA (44.948, -71.154). All sites were located in boreal wetlands, but the Alberta site is unique in hosting a large concentration of breeding Rusty Blackbirds in a single wetland, with $>30$ pairs in the McLelland Lake fen. One corner of the fen contained at least 8 breeding pairs in a $0.4 \mathrm{~km}^{2}$ area, which far exceeds typical nest densities of this species (reported as an average of 2.2 to 3.4 nests/ $\mathrm{km}^{2}$ in Matsuoka et al. 2010; but see Powell et al. 2010).

We deployed archival GPS tags (models PinPoint-10 and PinPoint-50 "store-on-board" tags, Lotek Wireless, Inc.) on adult birds using leg-loop harnesses (Rappole and Tipton 1991) with $1.5 \mathrm{~mm}$ stretch bead cord (Stretch Magic, Pepperell Braiding Company) pre-fitted and melted to itself with a soldering iron. We preferentially deployed on males and large females to keep tag weight (1.5-2.5 grams) close to $4 \%$ of the bird's body weight. Over three years, we deployed 30 tags across the three sites ( 8 in Alaska, 19 in Alberta, 3 in New Hampshire), and returned the following years to recover tags and retrieve the GPS data. In total, we re-sighted 9 tagged birds the year after deployment (return rate $=30 \%$ ) and recovered 7 of these tags ( 2 from Alaska, 4 from Alberta, 1 from New Hampshire). These 7 tags recorded a total of 522 GPS locations (Table 1) and failed 116 attempted locations. All GPS data are stored in Movebank (Kranstauber et al. 2011) and included in the Arctic Animal Movement Archive (Davidson et al. 2020).

Due to different tag models and a mid-study upgrade in technology allowing for more GPS points, location fix schedules differed for each deployment year. Tags deployed in Alaska and Alberta in 2015 attempted GPS fixes (10-meter accuracy) once every 5 days during fall and spring migration and once a week during the winter period (50 attempted fixes total, $n=16$ tags deployed, 4 recovered); Alberta 2017 tags attempted fixes once a day during migration and once every 3 days during winter (194 fixes total, $n=11$ tags deployed, 2 recovered); and New Hampshire 2018 tags attempted fixes once every 3-4 days during migration and once every 15 days during the winter ( 50 fixes total, $n=3$ tags deployed, 1 recovered). In addition, the points were split between roosting (before sunrise) and foraging (after sunrise) periods.

\section{Migratory connectivity}

Due to the small number of tags recovered, we did not calculate a standardized measure of migratory connectivity (Cohen et al. 2018). Instead, we report general patterns of migratory routes and wintering locations for the tagged birds (Webster et al. 2002). We also present wintering locations from three light-level geolocators retrieved in Alaska in 2010 (Johnson et al. 2012), and one band recovery record of a breeding bird recaptured in the winter (Smith 2013). These 11 individuals represent all of the Rusty Blackbirds we know to have been tracked from breeding to wintering grounds. To facilitate interpretation of connectivity data, we used a combination of eBird abundance data (Fink et al. 2020), geographic barriers, and land-cover differences to delineate three primary Rusty Blackbird wintering regions (Fig.
1): the Southeastern Coastal Plain (approximately New Jersey to Florida), the Mississippi Alluvial Valley (Illinois to Louisiana), and the Great Plains (Nebraska to Texas).

\section{Annual cycle phenology}

To determine how much time each bird spent in stationary versus migratory periods, we visually inspected GPS data and calculated distance traveled between consecutive points using the Haversine method in the "geosphere" package (Hijmans 2019) for program $\mathrm{R}$. We defined seasonal periods using the following criteria. (1) The "breeding" period was the time when birds were on territory ( $<5 \mathrm{~km}$ from capture location). (2) The "post-breeding" period (exhibited by some birds) was a stationary period at least one day in duration in close proximity $(<50 \mathrm{~km})$ to the breeding territory, and often north of the breeding site (thus not a clear migratory stopover). (3) "Fall migration" began with the onset of southward movement and ended when a wintering site was reached. (4) "Winter" periods were defined as any stationary periods following the cessation of significant southward movement and before the onset of northward movement in the spring. (5) "Spring migration" began with the onset of northward movement and ended when the individual reached its breeding territory. Migration periods consisted of both migratory movements and stopovers (stationary periods $>1$ day). Since previous stopover work on Rusty Blackbirds found they can travel $>5 \mathrm{~km} /$ day from their roosts to foraging areas, and roam up to $20-30 \mathrm{~km}$ during stopover events (Wright et al. 2018), we defined migratory movements as unidirectional movements that were $>5 \mathrm{~km} /$ day from the previous point in a seasonally appropriate direction. Thus, some stopovers or other stationary periods may cover an area $>30 \mathrm{~km}$ across because they consist of multidirectional or seasonally inappropriate movements, while some migratory movements are $<10 \mathrm{~km}$. Furthermore, several individuals exhibited multiple stationary periods during the winter, some of which were difficult to distinguish from fall stopovers. To summarize the variation in size of stationary areas, we calculated minimum convex polygons of all stopover, winter, and postbreeding sites in ArcMap (version 10.4; ESRI, Redlands, California). Finally, to determine if lengths of migratory flight segments were influenced by duration of the preceding stopover period, we calculated Spearman's rank correlation coefficient between stopover duration (in days) and distance traveled (in $\mathrm{km}$ ) during the three days following each stopover event $(n=26$ stopovers in both seasons combined).

\section{Habitat use}

We report habitat use of tagged birds by summarizing the proportions of GPS points that were located in different habitat types, separating locations by both season (fall, winter, and spring) and behavior (foraging and roosting). To find the habitat type at each GPS location, we used two remotely sensed GIS land cover layers: for the U.S, we used the USGS National Land Cover Database (NLCD; Homer et al. 2020); for Canada, we used the Ducks Unlimited Canada Enhanced Wetland Classification (DUC-EWC). Since the DUC-EWC layer includes many more wetland habitat classifications than the NLCD, to make the two databases compatible we simplified DUC-EWC classifications to match the two NLCD wetland habitat types: woody wetlands and emergent herbaceous wetlands. To calculate the proportions of habitat use by season and behavior, we pooled all tagged birds 
Fig. 2. Phenology of annual cycle stages and stationary/movement periods for each tagged Rusty Blackbird (Euphagus carolinus), beginning on June 1st of the deployment year and ending on May 31 st of the tag retrieval year. See text for details on how annual cycle stages were determined. Since several birds exhibited multiple stationary periods during the wintering period, each stationary period during winter is represented as a different shade of blue. "Unknown stages" occur when the exact timing of transition between major annual cycle stages is not known, due to time gaps in scheduled GPS fixes or tag failure. Likewise, unknown periods during annual cycle stages ("Breeding (unk)", "Fall (unk)", "Winter (unk)", "Spring (unk)") occur when we can confirm birds are in a particular stage, but we are unable to determine whether those days were spent moving ("Migratory movement") or stationary (e.g., "Fall stopover" or "Post-breeding"). For example, Alberta bird 1677 made seven stopovers during the fall (dark brown), punctuated by migratory movement days (black), with one short period of uncertainty (light brown) at the end of the fall when GPS fixes were scheduled 3 days apart.

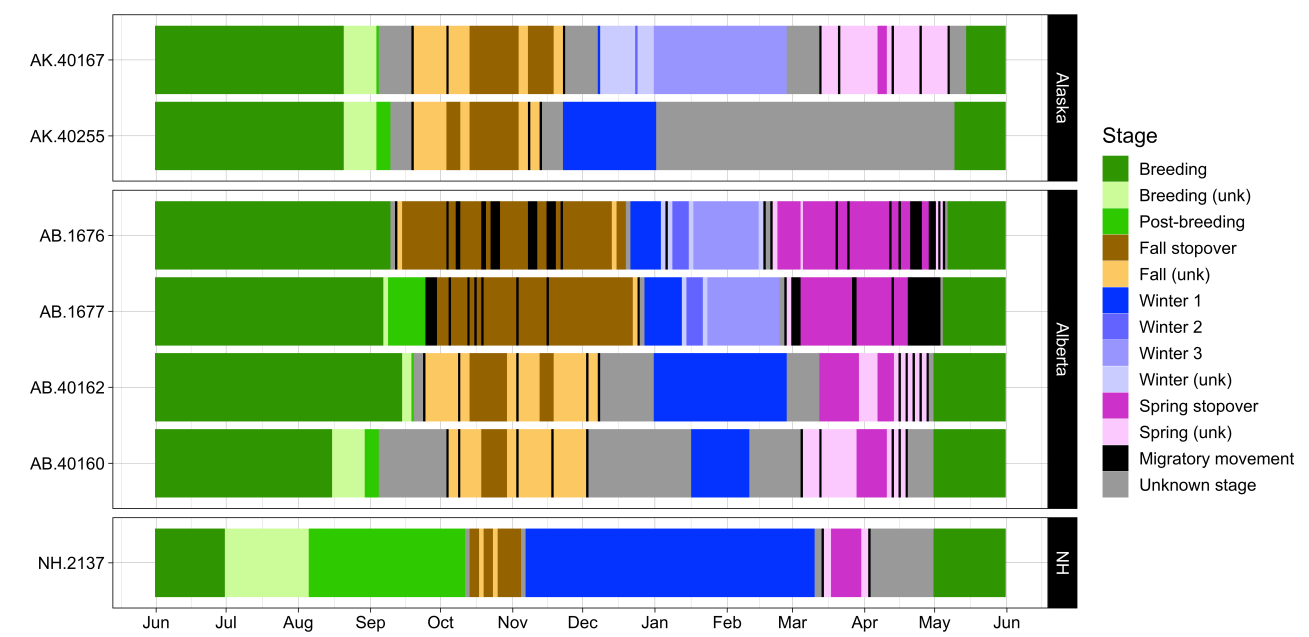

due to low sample sizes for individual birds. Due to the small number of points recorded during the breeding and post-breeding seasons, we excluded them from analyses. To avoid using points that may have been taken while the bird was actively migrating (and thus not using the habitat at that location), we excluded points whose altitude was $>100 \mathrm{~m}$ above the actual elevation of the land.

\section{RESULTS}

\section{Migratory connectivity}

The GPS tracks (Fig. 1) showed all Alberta individuals and 1 Alaska individual overwintering in the lower Mississippi Alluvial Valley and following a narrow flyway (185-350 km wide) along the Boreal Transition/Prairie Pothole zones during both fall and spring migrations. The other Alaska individual overwintered in the Great Plains region of Oklahoma and followed a parallel migratory route slightly west of the other western birds. The New Hampshire individual followed a migratory route between the Appalachians and the Atlantic coast, and traveled a much shorter distance to its wintering site $(1,200 \mathrm{~km})$ in the Southeastern Coastal Plains compared to the birds from Alberta $(\sim 3,400 \mathrm{~km})$ or Alaska $(\sim 5,000 \mathrm{~km})$. When including the three geolocators (Johnson et al. 2012) and one band recovery, Alaska birds ( $\mathrm{n}=$ 6) appear equally likely to overwinter in the Mississippi Valley as in the Great Plains (3 birds in each wintering region; Fig. 1).

\section{Annual cycle phenology}

Individual birds displayed variation in duration of annual cycle stages (Table 1, Fig. 2). Although data gaps created by the GPS schedule and tag failure resulted in some uncertainty around the points of transition from one stage to another, breeding latitude and total migration distance appeared to explain some of this variation, as the lower latitude New Hampshire individual had shorter migrations and longer post-breeding and wintering periods than the higher latitude Alaska and Alberta individuals. Several birds exhibited three wintering sites (but see Discussion), sometimes only remaining at a site for 6-9 days, whereas the New Hampshire bird spent $34 \%$ of the year at a single wintering site in North Carolina. For the two individuals with detailed movement data (Alberta 1676 and 1677), both fall and spring migrations lasted longer than the wintering period (Table 1), with several stopovers lasting longer than some winter stationary events (Fig. 2, Table A1.1). In total, the tags recorded 40 stopovers, which ranged from 1 to 35 days (mean $\pm \mathrm{SE}=9.5 \pm 1.2$ days). All individuals made at least one extended stopover ( $>7$ days) during both migrations, with the exception of the two Alaska individuals whose tags either failed or took very few points during spring migration (Fig. 2, Table A1.1). Minimum convex polygons of stationary periods ranged widely, from 0.01 hectares for a weeklong winter period, to $505 \mathrm{~km}^{2}$ for a two-week-long fall stopover (Table A1.1). During known migratory movements $(n=97)$, the mean distance traveled per day $( \pm \mathrm{SE})$ was $129 \pm 13 \mathrm{~km}$, with a 
Table 1. Length of annual cycle stages of Rusty Blackbirds (Euphagus carolinus), as determined by archival GPS tags deployed on breeding individuals of three populations. The number of successful GPS fixes are displayed for each individual. The amount of time spent during each of five annual cycle stages is displayed as minimum to maximum number of days spent in that stage, since fix schedules and tag failures resulted in uncertainty between stage transitions. The proportion of the annual cycle of each stage is reported in parentheses for the minimum number of days.

\begin{tabular}{|c|c|c|c|c|c|c|c|c|c|}
\hline \multirow[b]{2}{*}{ Tag ID } & \multirow[b]{2}{*}{$\begin{array}{l}\text { Deployment } \\
\text { location }\end{array}$} & \multirow[b]{2}{*}{ Year } & \multirow[b]{2}{*}{$\begin{array}{l}\text { Successful } \\
\text { fixes }\end{array}$} & \multicolumn{6}{|c|}{$\begin{array}{l}\text { Length of annual cycle stages in days } \\
\text { (minimum proportion of annual cycle) }\end{array}$} \\
\hline & & & & $\begin{array}{c}\text { Breeding } \\
\text { season } \\
\text { (on territory) }\end{array}$ & $\begin{array}{l}\text { Post-breeding } \\
\text { site }\end{array}$ & Fall migration & Wintering & $\begin{array}{l}\text { Spring } \\
\text { migration }\end{array}$ & $\begin{array}{c}\text { Unknown } \\
\text { stage } \\
\text { (between } \\
\text { stages) }\end{array}$ \\
\hline 40167 & Alaska & 2015 & 23 & $\begin{array}{c}97-117 \\
(0.27)\end{array}$ & $\begin{array}{l}1-15 \\
(0.003)\end{array}$ & $\begin{array}{r}67-95 \\
(0.18)\end{array}$ & $\begin{array}{c}81-109 \\
(0.22)\end{array}$ & $\begin{array}{r}57-77 \\
(0.16)\end{array}$ & $\begin{array}{c}48 \\
(0.13)\end{array}$ \\
\hline 40255 & Alaska & 2015 & 17 & $\begin{array}{l}103-244 \\
(0.28)\end{array}$ & $\begin{array}{l}6-29 \\
(0.02)\end{array}$ & $\begin{array}{r}57-75 \\
(0.16)\end{array}$ & $\begin{array}{c}39-175 \\
(0.11)\end{array}$ & $\begin{array}{l}1-128 \\
(0.003)\end{array}$ & $\begin{array}{l}145 \\
(0.40)\end{array}$ \\
\hline 1676 & Alberta & 2017 & 192 & $\begin{array}{l}125-128 \\
(0.34)\end{array}$ & $\begin{array}{c}0-2 \\
(0)\end{array}$ & $\begin{array}{l}100-104 \\
(0.27)\end{array}$ & $\begin{array}{c}56-60 \\
(0.15)\end{array}$ & $\begin{array}{l}77-80 \\
(0.21)\end{array}$ & $\begin{array}{c}7 \\
(0.02)\end{array}$ \\
\hline 1677 & Alberta & 2017 & 193 & $\begin{array}{c}124-129 \\
(0.34)\end{array}$ & $\begin{array}{c}15-18 \\
(0.04)\end{array}$ & $\begin{array}{r}94-97 \\
(0.26)\end{array}$ & $\begin{array}{c}55-60 \\
(0.15)\end{array}$ & $\begin{array}{r}67-71 \\
(0.18)\end{array}$ & $\begin{array}{c}7 \\
(0.02)\end{array}$ \\
\hline 40162 & Alberta & 2015 & 31 & $\begin{array}{c}136-142 \\
(0.37)\end{array}$ & $\begin{array}{c}1-9 \\
(0.003)\end{array}$ & $\begin{array}{c}77-104 \\
(0.21)\end{array}$ & $\begin{array}{r}56-93 \\
(0.15)\end{array}$ & $\begin{array}{c}48-64 \\
(0.13)\end{array}$ & $\begin{array}{c}43 \\
(0.12)\end{array}$ \\
\hline 40160 & Alberta & 2015 & 23 & $\begin{array}{c}106-131 \\
(0.29)\end{array}$ & $\begin{array}{l}6-49 \\
(0.02)\end{array}$ & $\begin{array}{c}62-135 \\
(0.17)\end{array}$ & $\begin{array}{r}25-90 \\
(0.07)\end{array}$ & $\begin{array}{r}47-69 \\
(0.13)\end{array}$ & $\begin{array}{l}105 \\
(0.29)\end{array}$ \\
\hline 2137 & $\begin{array}{c}\text { New } \\
\text { Hampshire }\end{array}$ & 2018 & 43 & $\begin{array}{c}61-124 \\
(0.17)\end{array}$ & $\begin{array}{c}67-105 \\
(0.18)\end{array}$ & $\begin{array}{r}23-27 \\
(0.06)\end{array}$ & $\begin{array}{c}123-128 \\
(0.34)\end{array}$ & $\begin{array}{r}21-51 \\
(0.06)\end{array}$ & $\begin{array}{c}34 \\
(0.09)\end{array}$ \\
\hline
\end{tabular}

maximum distance of $714 \mathrm{~km}$ completed by Alberta bird 1676 during fall migration. This long flight was preceded by an 18-day stopover in the Boreal Transition zone of Saskatchewan. In general, however, stopover duration was not correlated with distance moved following departure from the stopover site (Spearman's rho $=-0.14, \mathrm{P}=0.48$ ).

\section{Habitat use}

Throughout the total nonbreeding period ( $\mathrm{n}=414$ points), GIS land cover classifications showed woody wetlands $(21 \%$ of points), emergent herbaceous wetlands ( $22 \%$ of points), and cropland ( $23 \%$ of points) were used most often (Fig. 3A). However, upon visual inspection of satellite imagery, many points that were assigned to cropland were within several meters of small wetlands, so it is likely that birds were often using these small wetlands or edges surrounded by vast areas of cropland. In the winter period, individuals used emergent wetlands $(9 \%)$ much less often than during the migration periods $(30 \%$ in fall; $19 \%$ in spring), but developed areas (usually residential) were used more ( $14 \%$ in winter; $2 \%$ in fall; $5 \%$ in spring). Hay/pasture was used more heavily in the spring $(18 \%)$ than in the winter $(8 \%)$ or fall $(4 \%)$. When separating habitat use by behavior (nocturnal roosting, $n=266$ points; diurnal foraging, $n=148$ points; Figure 3B), individuals used emergent marsh substantially more for roosting $(30 \%)$ than foraging $(9 \%)$, while woody wetland use was reversed (13\% for roosting, 35\% for foraging).

\section{DISCUSSION}

With the miniaturization of bio-logging technology, there has been a rapid expansion of full annual cycle research on migratory songbirds (McKinnon and Love 2018). In particular, chronically understudied stages of the annual cycle, such as migration and wintering periods (Marra et al. 2015), have been increasingly
Fig. 3. Stacked bar plots showing the proportion of tagged Rusty Blackbird (Euphagus carolinus) nonbreeding GPS points that were located in different habitat types, separated by season (A) and behavior (B). Habitat types correspond to the USGS National Land Cover Database. Sample sizes for each category are displayed on the $\mathrm{x}$ axis.

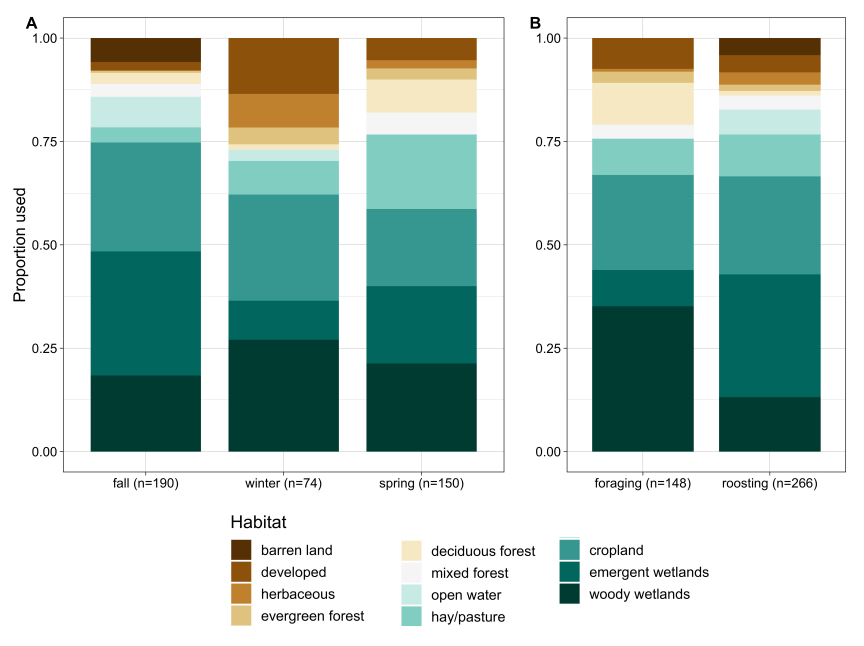

illuminated with the use of archival GPS tags (e.g., Hallworth and Marra 2015, Fraser et al. 2017, Ng et al. 2018, Tonra et al. 2019b). Our study adds to this growing body of knowledge, in particular by providing a high level of detail on individual migratory behavior of a rapidly declining temperate migratory bird. Despite a small sample size, we were able to reveal flexible stopover strategies and habitat use across the migratory period for one eastern and two western populations of Rusty Blackbirds. 


\section{Migratory connectivity}

Our results of migratory connectivity support and add to the two previous studies of Rusty Blackbird connectivity. As expected, the one New Hampshire bird overwintered in the Southeastern Coastal Plain, providing more evidence that the Appalachians serve as a migratory divide separating eastern breeding populations from central and western populations on the wintering grounds (Hobson et al. 2010). This divide is also supported by recent genomic work on the breeding grounds (Wilson et al. 2021). Likewise, just as the previous geolocator study showed Alaska individuals overwintering in both the Great Plains and Mississippi Valley (Johnson et al. 2012), we confirmed that Alaska breeders are not strongly linked to a single overwintering area. Our results also corroborate the conclusions of those authors that the Prairie Pothole region from southern Saskatchewan to Iowa is an important stopover region for migrating Rusty Blackbirds. The major flyway identified in our study, however, was somewhat further north and east, following the Boreal Transition zone and highlighting Minnesota and Wisconsin rather than the Dakotas as a key stopover region - of 19 extended stopovers ( $>7$ days) recorded for western birds, six (32\%) occurred in Minnesota and Wisconsin and four (21\%) in the Boreal Plains and Prairie Potholes of Saskatchewan. The other important stopover region for our birds was the upper Mississippi Alluvial Plains and Corn Belt Plains of eastern Iowa, Illinois, and western Indiana, with a further six extended stopovers $(32 \%)$ in this region. All Alberta individuals and one Alaska individual used this flyway to reach the lower Mississippi Valley, suggesting it is of great importance to multiple western breeding populations. The predominant use of the lower Mississippi Valley for overwintering echoes previous studies and eBird abundance data (Avery 2020, Fink et al. 2020), and further highlights the importance of managing and preserving appropriate habitat in this region for Rusty Blackbirds in the nonbreeding period.

\section{Annual cycle phenology}

Our analysis of annual cycle stages and migratory behavior revealed that for western birds, the amount of time spent on both fall and spring migration was similar to or longer than the time spent on the wintering grounds (Table 1). Indeed, for the birds with detailed movement data, delineating between fall migration and wintering periods seemed somewhat arbitrary, as there was no clear difference in duration or area of stationary events during these periods. Spring migration also included long stationary events but was more easily recognized since birds made large northward movements $(>250 \mathrm{~km})$ at the onset of spring migration. Our results support the findings of other studies that have recorded long stopovers of $\sim 1$ month in Rusty Blackbirds (Johnson et al. 2012, Wright et al. 2018a). The readiness to make large-scale movements during the winter and long stationary periods during migration is unusual for an obligate migrant, suggesting they display a high degree of phenotypic flexibility in regards to their life-history stage transitions (Wingfield 2008). Rather than showing two fixed syndromes of migratory and wintering behaviors, Rusty Blackbirds may instead exhibit a flexible migratory-nonbreeding stage more typical of facultative migrants, where movements and stationary periods are driven by exogenous factors such as weather and resources (Newton 2012), and equally possible at any point throughout the nonbreeding period. This flexibility has been documented in other short- to medium-distance obligate migrants like Yellow-rumped Warblers (Setophaga coronata), which can have a protracted migration and make facultative movements during the winter (Hunt and Flaspohler 2020).

An additional factor that may influence the timing and duration of stationary periods for Rusty Blackbirds is the existence of an extensive prealternate molt (Mettke-Hofmann et al. 2010, Wright et al. 2018b). As most birds likely begin this molt on the wintering grounds (Mettke-Hofmann et al. 2010) and complete it during spring migration (Wright et al. 2018b), the decision to make long stopovers or staging events may depend on the progression of molt (Wright et al. 2018a) and where individuals can find sufficient resources to fill this energetic demand. Notably, the single New Hampshire individual lacked the nomadic behavior during the nonbreeding period, but whether this is truly representative of eastern populations remains to be seen. Finally, although our sample size precluded us from investigating the impacts of weather on migration, there were several movements that were clear responses to winter storms (Fig. A1.1), demonstrating the degree to which extreme weather events can shape facultative movements during migration (Lack 1960).

\section{Habitat use}

The habitats used by Rusty Blackbirds during fall and spring migration in our study approximately coincide with previous studies and observations of the species. Wright et al. (2020) found that birds at a stopover site in Ohio strongly selected woody wetland types - dogwood-willow swamp and flooded forest - for foraging in both seasons, but also preferred areas of habitat complexity. In particular, birds rarely used the same habitats for nocturnal roosting as they did for diurnal foraging, almost exclusively selecting emergent marsh for roost sites. Our study also found a disparity in roosting and foraging habitat, as woody wetlands were often used for foraging but not roosting. The apparent use of cultivated cropland is consistent with the many observations of migrating Rusty Blackbirds foraging in plowed fields and stubble (Avery 2020). However, given the vast extent of available cropland across the Midwest, and the proximity of many cropland use points to wetlands in our study, our results may suggest that although some birds may regularly use cropland, they prefer sites that are in close proximity to both woody and emergent wetlands, which more reliably contain their preferred microhabitats (i.e., shallow water and leaf litter; Wright et al. 2020).

\section{CONCLUSIONS}

Although the sample size of this study restricted our capacity to make species-level inferences of migratory connectivity and yearround habitat selection, there are several important implications for future conservation and management of this species. First, given the large amount of time spent in fall and spring migration (up to $48 \%$ of the annual cycle), conservation efforts should target stopover regions at least as much as they target the wintering grounds. Second, we have identified likely key stopover regions for western breeding populations, especially the upper Mississippi Alluvial Plains and Boreal Transition/Prairie Pothole region of the northern Midwest U.S. and central Canada (see Table A1.2 for a list of all stationary sites). We cannot, however, identify 
specific stopover sites of importance, as no stopover site was used more than once by our tagged birds, but additional tracking and occupancy studies (such as Evans et al. 2021) may fill this gap. Finally, the differing habitats used for roosting and foraging suggests birds should have access to both emergent marsh and woody wetlands during the nonbreeding period, although further research is needed to determine if this pattern holds across the entire nonbreeding range. The flexible nonbreeding behavior of these birds suggests that they may be adaptable to changing climate and environmental conditions during this portion of the annual cycle, but this adaptability likely will not extend to their breeding period. Rusty Blackbirds are expected to lose at least $64 \%$ of their core boreal wetland breeding habitat by the end of this century (Stralberg et al. 2015). As such, a useful avenue of future research will be determining how connected or isolated different breeding populations are, and thus which populations are at greatest risk of local extinction, perhaps through investigation of juvenile recruitment and dispersal rates or rangewide genetic analyses (Wilson et al. 2021).

Responses to this article can be read online at: https://www.ace-eco.org/issues/responses.php/1871

\section{Acknowledgments:}

This paper is dedicated to the ongoing legacy of Russ Greenberg, whose passion for this marvelous but rapidly declining species has inspired Rusty Blackbird research for the last 20 years. For assistance in the field and with logistics, we thank Elly Knight, Hedwig Lankau, and Jesse Watson (Alberta); Luke DeCicco, Steve Matsuoka, Laura McDuffie, Kristy Rouse, and Marian Snively (Alaska); Charlotte Harding, Adrienne Leppold, and Patricia Wohner (New Hampshire). We also thank cooperating landowner Wagner Forest Management (New Hampshire). For use of the DUC-EWC, we thank Ducks Unlimited Canada, Ducks Unlimited Inc., The Pew Charitable Trusts, United States Fish and Wildlife Service (NAWCA), United States Forest Service, Government of Alberta (Environment and Parks), Government of Saskatchewan (Ministry of Environment), Alberta-Pacific Forest Industries Inc., Mistik Management Ltd., Suncor Energy Foundation, Louisiana Pacific Building Products, and the Forest Products Association of Canada (FPAC). Funding Statement: Tags and tag deployment was funded in part by a grant to The Migratory Connectivity Project from ConocoPhillips. Field work in Alberta funded by the Natural Sciences and Engineering Council. Field work in Alaska funded by the Alaska Department of Fish and Game-Threatened, Endangered and Diversity Program; CES/CEIS Joint Base ElmendorfRichardson; and United States Fish and Wildlife Service Migratory Bird Management, Alaska Region. Field work in New Hampshire funded by Arthur L. and Elaine V. Johnson Foundation; Wagner Forest Management; Conservation Biology Research Fund at the NH Charitable Foundation; and Maine Outdoor Heritage Fund. Ethics Statement: Field methods in Canada were approved by the University of Alberta Animal Care, protocol AUP00001523; Alberta Wildlife Research Permit and Collection License 18-581; and Environment and Climate Change Canada - Banding Permit 10277. Field methods in Alaska were approved by Institutional Animal Care and Use Committees of the US Fish and Wildlife
Service, Alaska Department of Fish and Game, and the U.S. Geological Survey Bird Banding Laboratory. Field methods in New Hampshire were approved by the Institutional Animal Care and Use Committee of the University of Maine. Author Contributions: Johnson, Marra, Powell, and Bayne conceived of the study. All authors collected field data and contributed to manuscript writing. Wright completed statistical analysis and wrote the first draft of the manuscript. Marra, Johnson, Bayne, and Foss acquired funding and supervised research.

\section{LITERATURE CITED}

Avery, M. L. 2020. Rusty Blackbird (Euphagus carolinus), version 1.0. In A. F. Poole, editor. Birds of the World. Cornell Lab of Ornithology, Ithaca, New York, USA. https://doi.org/10.2173/ bow.rusbla.01

Barnard, W. H., C. Mettke-Hofmann, and S. M. Matsuoka. 2010. Prevalence of hematozoa infections among breeding and wintering Rusty Blackbirds. Condor 112:849-853. https://doi. org/10.1525/cond.2010.100143

Cohen, E. B., J. A. Hostetler, M. T. Hallworth, C. S. Rushing, T. S. Sillett, and P. P. Marra. 2018. Quantifying the strength of migratory connectivity. Methods in Ecology and Evolution 9:513-524. https://doi.org/10.1111/2041-210X.12916

Davidson, S. C., G. Bohrer, E. Gurarie, S. LaPoint, P. J. Mahoney, N. T. Boelman, J. U. H. Eitel, L. R. Prugh, L. A. Vierling, J. Jennewein, et al. 2020. Ecological insights from three decades of animal tracking across a changing Arctic. Science 370:712-715. https://doi.org/10.1126/science.abb7080

Edmonds, S. T., D. C. Evers, D. A. Cristol, C. Mettke-Hofmann, L. L. Powell, A. J. McGann, J. W. Armiger, O. P. Lane, D. F. Tessler, P. Newell, K. Heyden, and N. J. O'Driscoll. 2010. Geographic and seasonal variation in mercury exposure of the declining Rusty Blackbird. Condor 112:789-799. https://doi.org/10.1525/cond.2010.100145

Evans, B. S., L. L. Powell, D. W. Demarest, S. M. Borchert, and R. S. Greenberg. 2021. Flock size predicts niche breadth and focal wintering regions for a rapidly declining boreal-breeding passerine, the Rusty Blackbird. Diversity 13(2):62. https://doi. org/10.3390/d13020062

Fink, D., T. Auer, A. Johnston, M. Strimas-Mackey, O. Robinson, S. Ligocki, B. Petersen, C. Wood, I. Davies, B. Sullivan, M. Iliff, and S. Kelling. 2020. eBird Status and Trends, data version: 2018; released: 2020. Cornell Lab of Ornithology, Ithaca, New York. https://doi.org/10.2173/ebirdst.2018

Fraser, K. C., A. Shave, A. Savage, A. Ritchie, K. Bell, J. Siegrist, J. D. Ray, K. Applegate, and M. Pearman. 2017. Determining fine-scale migratory connectivity and habitat selection for a migratory songbird by using new GPS technology. Journal of Avian Biology 48:339-345. https://doi.org/10.1111/jav.01091

Greenberg, R., and S. Droege. 1999. On the decline of the Rusty Blackbird and the use of ornithological literature to document long-term population trends. Conservation Biology 13:553-559. https://doi.org/10.1046/j.1523-1739.1999.97478.x

Hallworth, M. T., and P. P. Marra. 2015. Miniaturized GPS tags identify non-breeding territories of a small breeding migratory 
songbird. Scientific Reports 5:11069. https://doi.org/10.1038/ srep11069

Hijmans, R. J. 2019. geosphere: Spherical Trigonometry. R package version 1.5-10. https://CRAN.R-project.org/package= geosphere

Hobson, K. A., R. Greenberg, S. L. Van Wilgenburg, and C. Mettke-Hofmann. 2010. Migratory connectivity in the Rusty Blackbird: isotopic evidence from feathers of historical and contemporary specimens. Condor 112:778-788. https://doi. org/10.1525/cond.2010.100146

Homer, C., J. Dewitz, S. Jin, G. Xian, C. Costello, P. Danielson, L. Gass, M. Funk, J. Wickham, S. Stehman, R. Auch, and K. Riitters. 2020. Conterminous United States land cover change patterns 2001-2016 from the 2016 National Land Cover Database. ISPRS Journal of Photogrammetry and Remote Sensing 162:184-199. https://doi.org/10.1016/j.isprsjprs.2020.02.019

Hunt, P. D. and D. J. Flaspohler. 2020. Yellow-rumped Warbler (Setophaga coronata), version 1.0. In P. G. Rodewald, editor. Birds of the World. Cornell Lab of Ornithology, Ithaca, NY, USA. https://doi.org/10.2173/bow.yerwar.01

Johnson, J. A., S. M. Matsuoka, D. F. Tessler, R. Greenberg, and J. W. Fox. 2012. Identifying migratory pathways used by Rusty Blackbirds breeding in southcentral Alaska. Wilson Journal of Ornithology 124:698-703. https://doi.org/10.1676/1559-4491-124.4.698

Klaassen, R. H. G., M. Hake, R. Strandberg, B. J. Koks, C. Trierweiler, K.-M. Exo, F. Bairlein, and T. Alerstam. 2014. When and where does mortality occur in migratory birds? Direct evidence from long-term satellite tracking of raptors. Journal of Animal Ecology 83:176-184. https://doi.org/10.1111/1365-2656.12135

Kramer, G. R., D. E. Andersen, D. A. Buehler, P. B. Wood, S. M. Peterson, J. A. Lehman, K. R. Aldinger, L. P. Bulluck, S. Harding, J. A. Jones, J. P. Loegering, C. Smalling, R. Vallender, and H. M. Streby. 2018. Population trends in Vermivora warblers are linked to strong migratory connectivity. Proceedings of the National Academy of Sciences 115:E3192-E3200. https://doi.org/10.1073/ pnas. 1718985115

Kranstauber, B., A. Cameron, R. Weinzerl, T. Fountain, S. Tilak, M. Wikelski, and R. Kays. 2011. The Movebank data model for animal tracking. Environmental Modelling and Software 26:834-835. https://doi.org/10.1016/j.envsoft.2010.12.005

Lack, D. 1960. The influence of weather on passerine migration: a review. Auk 77:171-209. https://doi.org/10.2307/4082349

Luscier, J. D., S. E. Lehnen, and K. G. Smith. 2010. Habitat occupancy by Rusty Blackbirds wintering in the lower Mississippi Alluvial Valley. Condor 112:841-848. https://doi.org/10.1525/ cond.2010.100147

Marra, P. P., E. B. Cohen, S. R. Loss, J. E. Rutter, and C. M. Tonra. 2015. A call for full annual cycle research in animal ecology. Biology Letters 11:20150552. https://doi.org/10.1098/rsbl.2015.0552

Matsuoka, S. M., D. Shaw, and J. A. Johnson. 2010. Estimating the abundance of nesting Rusty Blackbirds in relation to wetland habitats in Alaska. Condor 112:825-833. https://doi.org/10.1525/ cond.2010.100148
McClure, C. J. W., B. W. Rolek, K. McDonald, and G. E. Hill. 2012. Climate change and the decline of a once common bird. Ecology and Evolution 2:370-378. https://doi.org/10.1002/ ece 3.95

McKinnon, E. A., and O. P. Love. 2018. Ten years tracking the migrations of small landbirds: Lessons learned in the golden age of bio-logging. Auk 135:834-856. https://doi.org/10.1642/ AUK-17-202.1

Mettke-Hofmann, C., P. B. Hamel, G. Hofmann, T. J. Zenzal Jr, A. Pellegrini, J. Malpass, M. Garfinkel, N. Schiff, and R. Greenberg. 2015. Competition and habitat quality influence age and sex distribution in wintering Rusty Blackbirds. PloS one 10: e0123775. https://doi.org/10.1371/journal.pone.0123775

Mettke-Hofmann, C., P. H. Sinclair, P. B. Hamel, and R. Greenberg. 2010. Implications of prebasic and a previously undescribed prealternate molt for aging Rusty Blackbirds. Condor 112:854-861. https://doi.org/10.1525/cond.2010.100150

Newton, I. 2012. Obligate and facultative migration in birds: ecological aspects. Journal of Ornithology 153:171-180. https:// doi.org/10.1007/s10336-011-0765-3

Ng, J. W., E. C. Knight, A. L. Scarpignato, A.-L. Harrison, E. M. Bayne, and P. P. Marra. 2018. First full annual cycle tracking of a declining aerial insectivorous bird, the Common Nighthawk (Chordeiles minor), identifies migration routes, nonbreeding habitat, and breeding site fidelity. Canadian Journal of Zoology 96:869-875. https://doi.org/10.1139/cjz-2017-0098

Niven, D. K., J. R. Sauer, G. S. Butcher, and W. A. Link. 2004. Christmas Bird Count provides insights into population change in land birds that breed in the boreal forest. American Birds 58:10-20.

Powell, L. L., T. P. Hodgman, W. E. Glanz, J. D. Osenton, and D. M. Ellis. 2010. A loose colony of Rusty Blackbirds nesting in northern Maine. Northeastern Naturalist 17:639-646. https://doi. org/10.1656/045.017.0409

Powell, L. L., T. P. Hodgman, I. J. Fiske, and W. E. Glanz. 2014. Habitat occupancy of Rusty Blackbirds (Euphagus carolinus) breeding in northern New England, USA. Condor 116:122-133. https://doi.org/10.1650/CONDOR-13-033-R1.1

R Core Team. 2018. R: A language and environment for statistical computing. R Foundation for Statistical Computing, Vienna, Austria. URL https://www.R-project.org/

Rappole, J. H., and A. R. Tipton. 1991. New harness design for attachment of radio transmitters to small passerines. Journal of Field Ornithology 62:335-337.

Reynolds, M. D., B. L. Sullivan, E. Hallstein, S. Matsumoto, S. Kelling, M. Merrifield, D. Fink, A. Johnston, W. M. Hochachka, N. E. Bruns, M. E. Reiter, et al. 2017. Dynamic conservation for migratory species. Science Advances 3:e1700707. https://doi. org/10.1126/sciadv. 1700707

Rosenberg, K. V., A. M. Dokter, P. J. Blancher, J. R. Sauer, A. C. Smith, P. A. Smith, J. C. Stanton, A. Panjabi, L. Helft, M. Parr, and P. P. Marra. 2019. Decline of the North American avifauna. Science 366:120-124. https://doi.org/10.1126/science.aaw1313 
Rushing, C. S., J. A. Hostetler, T. S. Sillett, P. P. Marra, J. A. Rotenberg, and T. B. Ryder. 2017. Spatial and temporal drivers of avian population dynamics across the annual cycle. Ecology 98:2837-2850. https://doi.org/10.1002/ecy.1967

Sillett, T. S., and R. T. Holmes. 2002. Variation in survivorship of a migratory songbird throughout its annual cycle. Journal of Animal Ecology 71:296-308. https://doi.org/10.1046/

j.1365-2656.2002.00599.x

Smith, G. J. 2013. The U.S. Geological Survey Bird Banding Laboratory: an integrated scientific program supporting research and conservation of North American birds. U.S. Geological Survey, OFR 2013-1238. https://doi.org/10.3133/ofr20131238

Stralberg, D., E. M. Bayne, S. G. Cumming, P. Sólymos, S. J. Song, and F. K. A. Schmiegelow. 2015. Conservation of future boreal forest bird communities considering lags in vegetation response to climate change: a modified refugia approach. Diversity and Distributions 21:1112-1128. https://doi.org/10.1111/ddi.12356

Tonra, C. M., M. T. Hallworth, T. J. Boves, J. Reese, L. P. Bulluck, M. Johnson, C. Viverette, K. Percy, E. M. Ames, A. Matthews, M. C. Slevin, R. R. Wilson, and E. I. Johnson. 2019a. Concentration of a widespread breeding population in a few critically important nonbreeding areas: Migratory connectivity in the Prothonotary Warbler. Condor 121:duz019. https://doi. org/10.1093/condor/duz019

Tonra, C. M., J. R. Wright, and S. N. Matthews. 2019b. Remote estimation of overwintering home ranges in an elusive, migratory nocturnal bird. Ecology and Evolution 9:12586-12599. https:// doi.org/10.1002/ece3.5723

Ward, M. P., T. J. Benson, J. Deppe, T. J. Zenzal, R. H. Diehl, A. Celis-Murillo, R. Bolus, and F. R. Moore. 2018. Estimating apparent survival of songbirds crossing the Gulf of Mexico during autumn migration. Proceedings of the Royal Society B: Biological Sciences 285:20181747. https://oi.org/10.1098/ rspb.2018.1747

Webster, M. S., P. P. Marra, S. M. Haig, S. Bensch, and R. T. Holmes. 2002. Links between worlds: unraveling migratory connectivity. Trends in Ecology \& Evolution 17:76-83. https://doi. org/10.1016/S0169-5347(01)02380-1

Wilson, R. E., S. M. Matsuoka, L. L. Powell, J. A. Johnson, D. W. Demarest, D. Stralberg, and S. A. Sonsthagen. 2021. Implications of historical and contemporary processes on genetic differentiation of a declining boreal songbird: the Rusty Blackbird. Diversity 13(3):103. https://doi.org/10.3390/d13030103

Wingfield, J. C. 2008. Organization of vertebrate annual cycles: implications for control mechanisms. Philosophical Transactions of the Royal Society B: Biological Sciences 363:425-441. https:// doi.org/10.1098/rstb.2007.2149
Wright, J. R., L. L. Powell, and C. M. Tonra. 2018a. Automated telemetry reveals staging behavior in a declining migratory passerine. Auk 135:461-476. https://doi.org/10.1642/auk-17-219.1

Wright, J. R., C. M. Tonra, and L. L. Powell. 2018b. Prealternate molt-migration in Rusty Blackbirds and its implications for stopover biology. Condor 120:507-516. https://doi.org/10.1650/ condor-17-177.1

Wright, J. R., L. L. Powell, S. N. Matthews, and C. M. Tonra. 2020. Rusty Blackbirds select areas of greater habitat complexity during stopover. Condor 122:1-18. https://doi.org/10.1093/ condor/duaa040
Editor-in-Chief: Keith A.Hobson Subject Editor: Scott Wilson
Sponsored by the Society of Canadian Ornithologists and Birds Canada

Parrainée par la Société des ornithologistes du Canada et Oiseaux Canada

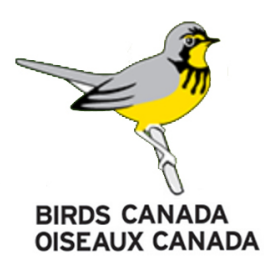




\section{APPENDIX 1}

Figure A1.1. Partial track of tagged Rusty Blackbird (Alberta 1676) on spring migration, showing 2 southward movements likely in response to severe weather: one movement of $60 \mathrm{~km}$ following heavy snowfall in eastern Iowa (https://www.weather.gov/dvn/summary 03242018), and another movement of $210 \mathrm{~km}$ following a record-breaking late winter storm in southern Minnesota (https://www.weather.gov/mpx/14Apr2018grade). GPS fixes are displayed as green circles, while arrows indicate the direction of movement. The dates and locations of stopover events and severe weather events are noted.

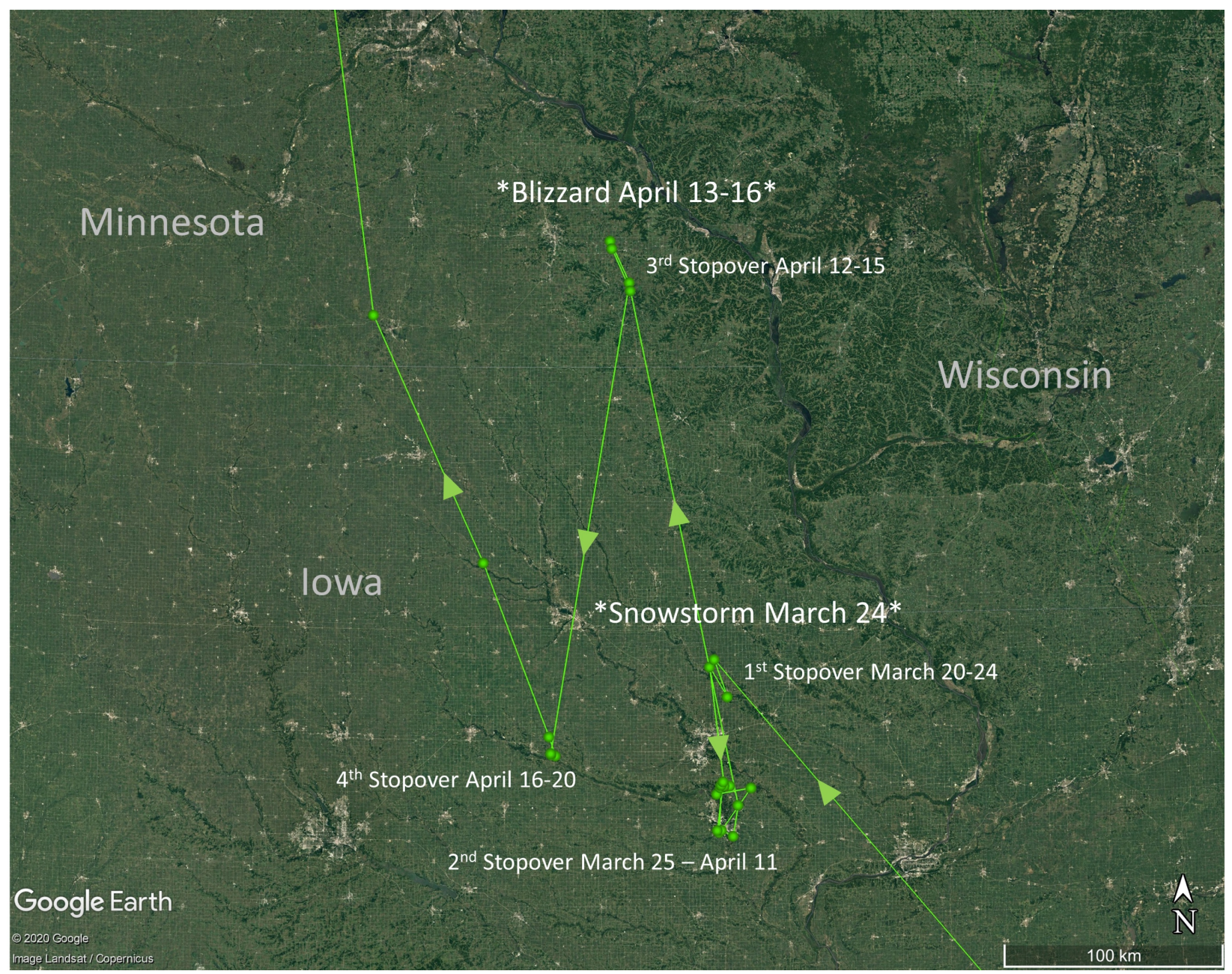


Table A1.1. Area of stationary events of GPS-tagged Rusty Blackbirds in successive stages of the annual cycle. Area is displayed in hectares of minimum convex polygons (MCPs), which were only calculated for stationary events with three or more GPS fixes. The number of points used to create the MCP and the number of days spent at that stationary event are reported in parentheses (n points, $\mathrm{n}$ days). Very small MCP areas $(<1 \mathrm{ha})$ occur when all the points are roost sites that were visited repeatedly.

\begin{tabular}{|c|c|c|c|c|c|}
\hline \multirow[b]{2}{*}{ Bird ID } & \multicolumn{5}{|c|}{ Annual cycle stage } \\
\hline & Breeding & Post-breeding & Fall Migration & Winter & Spring Migration \\
\hline AK.40167 & -- & -- & $28(3,20)$ & $231(4,56)$ & -- \\
\hline AK.40255 & -- & -- & $14(3,20)$ & $1576(5,39)$ & -- \\
\hline \multirow[t]{7}{*}{ AB. 1676} & $43(10,27)$ & -- & $8.0(18,18)$ & $0.3(5,12)$ & $146(6,9)$ \\
\hline & $2.9(13,24)$ & & $0.6(3,2)$ & $0.01(3,6)$ & $21558(14,13)$ \\
\hline & & & $4.9(9,8)$ & $1034(10,27)$ & $2665(5,4)$ \\
\hline & & & $56(12,11)$ & & $25385(17,17)$ \\
\hline & & & $0.1(4,3)$ & & $1787(4,3)$ \\
\hline & & & $32495(13,20)$ & & $787(5,4)$ \\
\hline & & & & & $248(3,2)$ \\
\hline \multirow[t]{5}{*}{ AB.1677 } & $3147(9,24)$ & $996(11,15)$ & $5065(5,4)$ & $110(6,15)$ & $29795(22,21)$ \\
\hline & $16(14,26)$ & & $542(7,6)$ & $0.9(3,6)$ & $6315(15,15)$ \\
\hline & & & $50532(14,13)$ & $1823(11,30)$ & $3402(7,6)$ \\
\hline & & & $21309(12,11)$ & & \\
\hline & & & $364(22,35)$ & & \\
\hline AB.40162 & $73(5,30)$ & -- & -- & $23(6,56)$ & -- \\
\hline AB.40160 & $1.0(3,6)$ & -- & -- & $637(3,24)$ & -- \\
\hline NH.2137 & -- & $5407(13,66)$ & $7992(4,9)$ & $221(16,123)$ & $10(4,12)$ \\
\hline
\end{tabular}


Table A1.2. Locations and descriptions of all stationary periods $>1$ day outside of the breeding territory, for 7 GPS-tagged Rusty Blackbirds. In "season" column, P = postbreeding, F = fall, W = winter, $\mathrm{S}=$ spring, and numbers indicate the sequential stationary events for each individual in that season. If stationary events occurred in or near protected areas, those sites are listed; "adjacent to" is defined as having points within $5 \mathrm{~km}$ of a protected area boundary. Levels III and IV Ecoregions as defined by the US Environmental Protection Agency are also listed.

\begin{tabular}{|c|c|c|c|c|c|}
\hline ID & Season & Length (days) & Location description & Known protected area & Ecoregion \\
\hline 1677 & P1 & 15 & Boreal forest and wetlands, $50 \mathrm{~km}$ East of Fort McKay, Wood Buffalo, AB & & $A B$, Boreal Forest, boundary of Central Mixedwood and Athabasca plain \\
\hline \multirow{2}{*}{1677} & F1 & 4 & Farmland and potholes, 3-12km South of Nipawin, SK & & SK, Boreal Plain, Boreal transition \\
\hline & F2 & 6 & $\begin{array}{l}\text { Potholes, farmland, and forest, } 14 \mathrm{~km} \text { SSE of San Clara, MB, } 10 \mathrm{~km} \mathrm{~W} \text { of } \\
\text { Duck Provincial Park Boundary }\end{array}$ & & MB, Boreal Plains, Mid-Boreal uplands \\
\hline 1677 & & & Wetlands, forest, and farmland between Shell Lake, Rice Lake, and & & \\
\hline 1677 & F5 & 13 & $\begin{array}{l}\text { Cumberland, Washburn and Barron Counties, WI } \\
\text { Wetlands along Miss. River between Upper Miss. River Wildlife and Fish }\end{array}$ & & 51a/b: WI, North Central Hardwood Forests \\
\hline 1677 & F6 & 11 & Refuge and Camanche, IA & Upper Mississippi River Wildlife and Fish Refuge, IA & 72d: IL/IA, Miss. River, Interior River Valleys and Hills, Upper Miss. Alluvial Plain \\
\hline 1677 & F7 & 35 & Wetlands of Big Lake NWR, AR & Big Lake National Wildlife Refuge, AR & 73c: AR, Miss. Alluvial Plain, St. Francis lowlands \\
\hline \multirow{2}{*}{1677} & W1 & 15 & Residential area, Clarksdale, MS & & 73a: MS, Miss. Alluvial Plain, Northern Holocene meander belts \\
\hline & W2 & 6 & $\begin{array}{l}\text { Wetlands and farmland, } 1 \mathrm{~km} \text { W of west boundary of Morgan Lake NWR, } \\
\text { MS }\end{array}$ & Morgan Lake National Wildlife Refuge, MS & 73a: MS, Miss. Alluvial Plain, Northern Holocene meander belts \\
\hline \multirow{2}{*}{1677} & w3 & 30 & Wetlands, forest, and farmland 3-6km NW to SW from Ripley, MS & & 65b: MS, Southeastern Plains, Flatwoods/Blackland Prairie margins \\
\hline & S1 & 21 & $\begin{array}{l}\text { Wetland and forest patches surrounded by farmland, } 7-23 \mathrm{~km} \mathrm{~S} \text { of } \\
\text { Lafayette, IN }\end{array}$ & & 55b: IN, eastern Corn Belt Plains, Loamy high lime till plains \\
\hline 1677 & S2 & 15 & $\begin{array}{l}\text { Wetlands and farmland } 2 \mathrm{~km} \text { W of Coffee Creek Watershed Preserve, } \\
4 \mathrm{~km} \mathrm{~S} \text { of Chesterton IN; and Ogden Dunes area of Indiana Dunes } \\
\text { National Park }\end{array}$ & $\begin{array}{l}\text { Adjacent to Coffee Creek Watershed Preserve and } \\
\text { Indiana Dunes National Park, IN }\end{array}$ & 54b: IN, Central Corn Belt Plains, Chicago Lake Plain \\
\hline 1677 & s3 & 6 & Farmland, forest, wetlands between Hanover and Footville, WI & & 53a: WI, Southeastern Wisconsin Till Plains, Rock River drift plain \\
\hline 1676 & F1 & 18 & Boreal lake/wetland 5-6km ESE of Shellbrook, SK & & SK, Boreal Plain ecozone, Boreal transition \\
\hline \multirow[t]{2}{*}{1676} & F2 & 2 & Wetlands, Agassiz NWR, MN & Agassiz National Wildlife Refuge, $\mathrm{MN}$ & 4bd: MN, Lake Agassiz Plains \\
\hline & & & Boreal wetlands, Flambeau River State Forest, $6 \mathrm{~km}$ W of Connors Lake & & \\
\hline 1676 & F3 & 8 & Recreation Area Beach Park, WI & Flambeau River State Forest, WI & 50g: WI, Northern Lakes and Forests, Chippewa Lobe rocky ground moraines \\
\hline 1676 & F4 & 1 & Wetlands, OwI Creek Fen Savanna State Natural Area, WI & Owl Creek Fen Savanna State Natural Area, WI & 51c: WI, North Central Hardwood Forests, Glacial Lake Wisconsin sand plain \\
\hline 1676 & F5 & 11 & Wetlands and forest, Mazomanie Bottoms State Natural Area, WI & Mazomanie Bottoms State Natural Area, WI & $52 \mathrm{~b}:$ WI, Driftless Area, Coulee Section \\
\hline \multirow[t]{2}{*}{1676} & F6 & 3 & Wetland and shrubland, Liberty Creek Wildlife Area, WI & Liberty Creek Wildlife Area, WI & 53a: WI, Southeastern Wisconsin Till Plains, Rock River drift plain \\
\hline & & & Forest, wetlands, and farmland along MS River, from $4 \mathrm{~km} \mathrm{~W}$ of Lake & & \\
\hline 1676 & F8 & 20 & Providence, south to $5 \mathrm{~km} \mathrm{SW}$ of Vicksburg Tallulah Regional Airport, LA & & 73a: LA, Miss. Alluvial Plain, Northern Holocene Meander Belts \\
\hline 1676 & W1 & 12 & Pastureland, $1 \mathrm{~km}$ NE of town of Parks, LA & & 73k: LA, Miss. Alluvial Plain, Southern Holecen meander belts \\
\hline 1676 & W2 & 6 & Wetlands, $5 \mathrm{~km}$ SW of southern boundary of Atchafalaya NWR, LA & Adjacent to Atchafalaya National Wildlife Refuge, LA & 73n: LA, Miss. Alluvial Plain, Inland swamps \\
\hline \multirow[t]{2}{*}{1676} & W3 & 27 & Gulf Coast wetlands, $3 \mathrm{~km} \mathrm{~N}$ to $8 \mathrm{~km}$ E of Weeks Island, LA & & 73n: LA, Miss. Alluvial Plain, Inland swamps \\
\hline & s1 & 9 & $\begin{array}{l}\text { Small wetland/forest patches surrounded by residential area, Fairview } \\
\text { Heights to Belleville, IL }\end{array}$ & & 72i: IL. Interior River Valleys and Hills, Southern Illinoian Till plain \\
\hline 1676 & & & Mosaic of forest/farmland/wetland/pastureland, Oak Run to & & \\
\hline \multirow[t]{2}{*}{1676} & S2 & 13 & Middlegrove, IL & & 72i: IL, Interior River Valleys and hills, Western dissected Illinoian till plain \\
\hline & S3 & 4 & $\begin{array}{l}\text { Wetlands surrounded by farmland, Robinson to Central City, IA, including } \\
\text { Wakpicada Natural Area }\end{array}$ & Wakpicada Natural Area, IA & 47c: IA, Western Corn Belt Plains, lowan Surface \\
\hline 1676 & & & Mix of wetland/forest/residential areas from $5 \mathrm{~km} \mathrm{~S}$ to $20 \mathrm{~km} \mathrm{~N}$ of lowa & & \\
\hline 1676 & S4 & 17 & City, IA, including Lake View OHV Park and Lake McBride State Park & Lake McBride State Park, IA & 47f: IA, Western Corn Belt Plains, Rolling Loess Prairies \\
\hline 1676 & S5 & 3 & Farmland/wetland/forest mosaic, $5 \mathrm{~km} \mathrm{~N}$ to $20 \mathrm{~km} \mathrm{SSE}$ of Dover, $\mathrm{MN}$ & & $52 \mathrm{~b} / \mathrm{c}: \mathrm{MN}$, Driftless Area, Blufflands and Coulees \\
\hline 1676 & S6 & 4 & $\begin{array}{l}\text { Wetlands of Otter Creek Marsh State Wildlife Refuge and surrounding } \\
\text { area, IA }\end{array}$ & Otter Creek Marsh State Wildlife Refuge, IA & 47f: IA, Western Corn Belt Plains, Rolling Loess Prairies \\
\hline & S7 & 2 & $\begin{array}{l}\text { Pastureland/wetland from } 9 \mathrm{~km} \mathrm{E} \text { to } 8 \mathrm{~km} \text { W of Lundar, MB, } 5 \mathrm{~km} \text { E of } \\
\text { shore of Lake Manitoba }\end{array}$ & & MB, Prairies, Lake Manitoba Plain \\
\hline 40160 & P1 & 5 & Boreal wetlands/forest, $60 \mathrm{~km} \mathrm{NE}$ of Fort McKay & & $A B$, Boreal Forest, boundary of Central Mixedwood and Athabasca plain \\
\hline \multirow[t]{2}{*}{40160} & F1 & 10 & $\begin{array}{l}\text { Wetland/farmland/lake mosaic, Hartfiel State Wildlife Mgmt Area south } \\
\text { to } 5 \mathrm{~km} \mathrm{E} \mathrm{of} \mathrm{Alexandria,} \mathrm{MN}\end{array}$ & Hartfiel State Wildlife Management Area, MN & 51j: MN, North Central Hardwoods, Alexandria moraines and Detroit lakes outwash plain \\
\hline & W1 & 24 & $\begin{array}{l}\text { Wetland/farmland mosaic, from Holly River to Cross Roads, AR, 2km } \\
\text { from White River NWR boundary }\end{array}$ & Adjacent to White River National Wildlife Refuge, AR & 73g: AR, Miss. Alluvial Plain, Western lowlands pleistocene valley trains \\
\hline & & & Farmland/forest/wetland mosaic, $20 \mathrm{~km}$ E of Madison to $9 \mathrm{~km} \mathrm{E}$ of & & \\
\hline 40160 & S1 & 12 & Evansville, WI & & 53c: WI, Southeastern Wisconsin Till plains, savannah and till plains \\
\hline 40162 & F1 & 15 & Boreal lakes/pastureland, $18 \mathrm{~km}$ WSW of Usherville, SK & & SK, Boreal Plain, Mid-boreal upland \\
\hline 40162 & F2 & 5 & Forest/farmland mosaic, $4 \mathrm{~km} \mathrm{~S}$ of Eleroy to Damascus, IL & & 54g: IL, Central Corn Belt Plains, Rock River hills \\
\hline 40162 & W1 & 56 & Floodplain, Huffs Island area along Arkansas River, AR & & 73h: AR, Miss. Alluvial Plain, Arkansas River holocene Meander belts \\
\hline 40162 & S1 & 16 & Black River floodplain, $4 \mathrm{~km}$ E of Allred Lake Natural Area, MO & Adjacent to Allred Lake Natural Area, MO & 73b: MO, Miss. Alluvial Plain, Pleistocene valley trains \\
\hline 40162 & S2 & 6 & Embarras River floodplain, $4 \mathrm{~km}$ W of Hardinville, IL & & 72a: IL, Interior River Valleys, Wabash-Ohio Bottomlands \\
\hline 40255 & P1 & 5 & Residential area/boreal forest edge, Wasilla, AK & & AK, Cook Inlet \\
\hline 40255 & $\mathrm{~F} 1$ & 5 & Boreal wetlands on edge of Gerry Lake, $21 \mathrm{~km}$ ENE of Hines Creek, AB & & AB, Boreal Forest, Dy Mixedwood \\
\hline 40255 & F2 & 20 & Boreal forest/potholes, 7km WSW of Rabbit Lake, SK & & SK, Boreal Plain/Prairie Pothole boundary, Boreal transition/Aspen parkland \\
\hline 40255 & W1 & 39 & Residential area of South Tulsa, OK, around Holland Hall school system & & 40b: OK, Central Irregular Plains, Osage Cuestas \\
\hline 40167 & $\mathrm{~F} 1$ & 20 & Potholes/farmland, 4km WNW of Dalmeny, SK & & Prairie Potholes, SK: moist mixed grassland/aspen parkland boundary \\
\hline 40167 & F2 & 10 & Wetland/forest/farmland, $7 \mathrm{~km} \mathrm{~S}$ of Alexandria, MN & & 51j: MN, Alexandria moraines and Detroit Lakes outwash region, North Cental Hardwoods \\
\hline 40167 & W3 & 56 & Forest/farmland/residential mosaic, 11km E of Olive Branch, MS & & 74b: MS, Miss. Valley, Loess Plains \\
\hline 40167 & s1 & 3 & Forest/farmland/wetland, adjacent to Lodi Marsh State Natural Area, WI & Adjacent to Lodi Marsh State Natural Area, WI & 53c: WI, Southeastern Wisconsin savannah and till plain \\
\hline 2137 & P1 & 66 & $\begin{array}{l}\text { Boreal forest/wetlands, 4-8km E to } 10 \mathrm{~km} \mathrm{~S} \text { of First Connecticut Lake, } \\
\text { northern } \mathrm{NH}\end{array}$ & & 58m: NH, Northeastern Highlands, Quebec/New England Boundary mountains \\
\hline 2137 & F1 & 3 & Forest/rural residential area, $3 \mathrm{~km} \mathrm{SW}$ of Blake Mountain, $\mathrm{NH}$ & & 58p: NH, Northeastern Highlands, White Mountains/Blue Mountains \\
\hline 2137 & F2 & 3 & Forest/farmland/rural mosaic, 3-7km SSE of Great Barrington, MA & & 58b: MA, Northeastern Highlands, Western New England Marble Valleys \\
\hline & & & $\begin{array}{l}\text { Swamp/forest/rural mosaic around Potomac River, } 8 \mathrm{~km} \mathrm{~S} \text { of La Plata, } \\
\text { MD to Fairview Beach, VA, including Zekiah Swamp Natural Environment }\end{array}$ & & \\
\hline 2137 & F3 & 9 & Area & Zekiah Swamp Natural Environment Area, MD & $65 \mathrm{~m}: \mathrm{MD}$ and VA, Potomac River, Southeastern Plains, rolling coastal plain \\
\hline 2137 & W1 & 123 & Forest/farm/wetland mosaic, 3km NNE of Fremont, NC & & $65 \mathrm{~m}: \mathrm{NC}$, Southeastern Plains, Rolling Coastal Plain \\
\hline & & & Swamp/forest 4-6km SE of Spart Township, NJ, adjacent to Rockaway & Adjacent to Rockaway River State Wildlife & \\
\hline 2137 & S1 & 12 & River State WMA and Weldon Brook State WMA & Management Area, NJ & 58i: NJ, Northeastern Highlands, Glaciated Reading prong \\
\hline
\end{tabular}

